\title{
The products of conception: the social context of reproductive choices
}

\author{
Barbara Katz Rothman Department of Sociology, Baruch College, City University of New York
}

\section{Author's abstract}

This paper addresses the changing ideology regarding reproduction, an evolving American, and potentially worldwide, value system regarding children and parenthood. Children are increasingly being seen as products, and the new technology of reproduction, including the sale of reproductive material and services and especially prenatal diagnosis and selective abortion, encourage this commodification of the fetus. While the new technology does indeed offer new choices, it also creates new structures and new limitations on choice. In the contemporary American social structure, these choices are inevitably couched in terms of production and commodification, and thus do not offer individuals genuine choice or control.

It troubles me when a pregnant woman, suspecting a bout of beer drinking may have harmed her baby, aborts, saying 'It'll only set us back three months'.

It troubles me when a friend talks about hiding her pregnancy from her daughters until after she has gotten her amniocentesis results because 'How could I explain an abortion to them?'

It troubles me when I am introduced to a pregnant woman and after giving her name she pats her belly and says 'And this is Heather'.

These issues which trouble me provide the impetus for this paper. Taken together, they speak to an evolving American value system regarding children and parenthood. I see them as representing further movement towards the commodification of life, towards treating people and parts of people - our organs, blood, energy - as commodities. When we talk about the buying and selling of blood, the banking of sperm, the costs of hiring a surrogate mother, we are talking about bodies as commodities. And when we talk about being able to 'afford' a second child, like a second car, then we are talking about children as luxury items, fine if you can afford them. And if all children are luxuries, then special children are special

\section{Keywords}

Prenatal diagnosis; reproduction; abortion; reproductive technology; commodification of people. luxuries, as when we talk about how many extra dollars a year it costs to raise a child with sickle cell disease.

In this value system, in this developing ideology, we are learning to see our children as products, the products of conception. Even while they still move within us, they are not part of us - we have learned to see them as other, as separate, as products. We work hard, some of us, at making the perfect product, what one of the doctors in the childbirth movement calls a 'blue ribbon baby'. Modern adoption practices have long encouraged us to think of babies as commodities: they are, after all, available for purchase.

The new technology of reproduction is building on this commodification. Rather than buying whole babies, we can now buy the parts. Sperm is relatively cheap. It is sold by students for approximately the costs of a textbook, or of an evening out. But it is the woman who supplies all of the work, the labour as it were. Purchasing the woman's services, if you can supply your own sperm ('surrogate mothers') is considerably more expensive. Egg donations are being done only on an experimental basis now: will they eventually become purchasable too? And what of embryo transplants? Doctors have tried to patent the embryo transfer process: how long will it be before human embryos, like animal embryos, are up for sale?

Even in a more usual, 'naturally' occurring pregnancy, the new technology of reproduction encourages and reinforces the commodification process: genetic counselling serves the function of quality control, and the wrongful life suits are a form of product liability litigation (1).

What is the underlying ideology that permits the development of such a technology? And what does it do to us to think this way? These are the questions which I grapple with in this paper.

I am not claiming that the technology itself is harmful. I think that the new technology of reproduction offers us an opportunity to work on our definitions of parenthood, of motherhood, fatherhood and childhood, to rethink and improve our relations with each other in families. Freed from some of the biological constraints, we could evolve better, more egalitarian ways of relating to our selves and each other in reproduction. The technology is a promise, beckoning us with new possibilities, limiting the role of 
chance and accident in reproduction, giving us new control. And the technology is a threat: control towards what end? for what purpose? Or will the technology simply be incorporated into the social order and bring no social change? Technological change in reproduction, whether the current ability to diagnose genetic disease in utero, the future ability to grow babies in test tubes, or the well-established ability to substitute artificial milk for mother's milk, does not necessarily mean social change. Think of how formula feeding might have changed men's and women's roles in childbearing.

Amniocentesis for prenatal diagnosis is an increasingly important part of the new technology of reproduction, affecting more and more pregnancies each year. By the 1990s it may very well become a standard, routine part of all prenatal care (2). In this procedure, a small amount of the amniotic fluid that surrounds the fetus is withdrawn during the 16th to 20th week of pregnancy, and fetal cells are cultured, a process which takes approximately four weeks. Studies of the fluid and fetal cells can detect a variety of abnormalities, notably Down's syndrome, but many others as well; hundreds of other genetic diseases, including sickle cell anaemia and Tay Sachs disease; and also the neural tube defects such as hydrocephalus and spina bifida. If the fetus is found to be diseased or damaged, in almost all cases abortion is the only treatment available.

For parents who have watched one child suffer and slowly, inevitably die with a condition like Tay Sachs disease, the availability of prenatal diagnosis can fundamentally change their reproductive options, when both parents are carriers of such a disease in each pregnancy they have a one in four chance of producing a fetus with the condition. Fortunately very few parents are faced with such high risks of reproductive tragedy. The much more common uses of prenatal diagnosis are for the neural tube defects, such as spina bifida, and for chromosomal disorders, especially Down's syndrome.

The chances of bearing a fetus with Down's syndrome, which causes mental retardation and is associated with some physical problems as well, rises with the age of both the mother and the father. There is no particular age at which the risk jumps dramatically, but rather the increase is steady. For a woman at age 30 the chances are roughly one in 1000 , at age 35 one in 350 , and at age 40 one in 100 . It may well be that other age-related factors - perhaps diet, general health, exposure to environmental toxins and radiation - are the real causes of Down's syndrome, and not age per se. So far however, age has been the only factor demonstrably linked to Down's syndrome in the general population.

When amniocentesis for the diagnosis of Down's syndrome was first introduced, it was for women over the age of 40 . Within ten years the medical standard dropped to age 35 , and is currently inching its way down to 33 or even lower in some centres.
Although some people have discussed the value of being forewarned of genetic or other diseases even in a pregnancy the woman intends to carry to term, abortion is an integral part of this new technology. $\overrightarrow{\vec{A}}$ Fetal treatments do not exist for these diseases. The $\stackrel{\text { ? }}{\circ}$ overwhelming majority of people who are told of serious disease or damage in the fetus do abort. These $\frac{\bar{D}}{\bar{N}}$ abortions, abortions to prevent the birth of a $\frac{\sigma}{\phi}$ handicapped or disabled child, are among the most $\stackrel{\varnothing}{\Omega}$ socially acceptable of abortions. In the United States, ळ over 80 per cent of people approve of the use of $\overrightarrow{0}$ abortion in this situation (3). Because they are socially acceptable, many people have assumed that they are $\vec{\omega}$ psychologically more acceptable than are abortions for what is called 'less reason', abortions because a woman does not want to be pregnant. That is not true. The reasons lie in the meaning of abortion for the women who use it.

Women's use of abortion for unwanted pregnancies $\stackrel{\infty}{\infty}$ has been perceived as a devaluing of motherhood. That $\frac{\circ}{\square}$ it is not. On the contrary, it is because women continue to take motherhood so very seriously that abortion is necessary. Women understand motherhood to change $\overparen{\Phi}$ their lives, to involve a deep and permanent $\frac{3}{\square}$ commitment. If women did not take motherhood seriously, other options for managing an unwanted $\vec{\varphi}$ pregnancy would be available, from simpie o abandonment to the sale of babies. The current market rate in America for a newborn baby is upwards of têे thousand dollars - but very few women are willing bear babies to give them away.

In a sense, the motherhood-abortion paradox $\frac{\partial}{\varnothing}$ parallels the marriage-divorce paradox. The divorce $\varrho$ rate is highest when expectations for marriage are $\overrightarrow{\overrightarrow{0}}$ highest. If marriage were considered less important, 3 less central to one's life, divorce would be less common. Thus the paradox is that the high divorce rate demonstrates not a devaluing of marriage but a commitment to the importance of the marriage $\Phi$ relationship; and abortion, as a solution to an $\frac{\sigma}{3}$. unwanted pregnancy demonstrates the importance to women of the mother-child relationship.

Abortions to prevent the birth of a disabled child may be more socially acceptable, but they are not in any other sense easier. They present a deeper, more fundamental challenge for both the individual woman and the society at large. The challenge is to the meaning of motherhood.

The meaning of the abortion lies in the meanings the pregnancy holds for the woman. If a woman sees a pregnancy as an accident, if for example her pregnancy is a by-product of contraception that did not work, then in her definition the fetus is not a person and not meant to be one. The abortion is the solution to the problem of failed contraception.

But if the fetus is to be her child, if she has chosen to have this baby - chosen by consciously and purposively becoming pregnant, or by willingly and openly $\frac{\varrho}{\sigma}$ accepting an unintended pregnancy - then she considers that fetus to be a person. It is her baby. She 
means it to be her baby. To abort an accident is one thing. To abort your baby, even your very imperfect baby, is something else again. And that is equally true even if two fetuses are identical in size, in ounces, and in 'viability'. There is an understanding in sociology, and a deeply held belief of mine, that situations defined as real are real in their consequences (3). If a woman defines the products of conception within her as accidental, then that is what they are. If she defines those products as her baby, then she treats them as her baby.

The problem, or one of the problems, with the technology of amniocentesis and selective abortion is what it does to us, to mothers and to fathers and to families. It sets up a contradiction in definitions. It asks women to accept their pregnancies and their babies, to take care of the babies within them, and yet be willing to abort them. We ask them to think about the needs of the coming baby, to fantasise about the baby, to begin to become the mother of the baby, and to be willing to abort the genetically damaged fetus. At the same time. For twenty to twenty-four weeks.

Women suffer in this contradiction of demands. They want to have amniocentesis to identify and to be able to abort a damaged fetus, but are afraid of the procedure's possible harm to their baby. As one couple said during a counselling session as they struggled with the (remote) possibility of miscarriage caused by amniocentesis, and the (equally remote) possibility of having a child with Down's syndrome:

'Husband: "We really want this baby ..." Wife: ". . . and if it's a healthy baby I really hate the thought of losing this person".'

If it is healthy, if it is genetically acceptable, then it is a person, her baby. If it is not, then it is just a fetus, a genetically damaged fetus.

Parenthood demands such total acceptance from us. We expect mothers to love, to accept their babies unreservedly, with the fullness of their hearts, no matter what. We joke about it: 'A face only a mother could love'. It is not that women have always been able to achieve that unconditional love. Indeed, the fear of having a child one cannot love is one of the more common fears that haunt pregnancy. But never before have we asked women to make rational, intellectual determinations based on that fear. What does it do to motherhood, to women, and to men as fathers too, when we make parental acceptance conditional, pending further testing? We ask the mother and her family to say, in essence, 'These are my standards. If you meet these standards of acceptability, then you are mine and I will love and accept you totally. After you pass this test'.

The amniocentesis comes so late in the pregnancy. The problems will be very different when fetal testing is done earlier in pregnancy. But now there are months that women wait in this limbo of 'tentative pregnancy', unsure whether they are 'mothers' or 'carriers of a defective fetus'. For some women the amniocentesis comes too late:

'. . by the time the results came in, the baby had been leaping in my womb for a month ... During one of the sleepless nights before the results were in I decided I would raise the child if it looked like ET (4)'.

A face only a mother could love.

An irony in all this is that the technology still cannot guarantee a 'blue ribbon baby'. A fetus can pass all of the tests, and still be far from perfect at birth. A child can be born or become retarded, crippled, disfigured from thousands of causes. One can rationally decide to abort a fetus with spina bifida because life in a wheelchair is not acceptable - and then have a baby's back broken in a car accident. One can choose not to carry to term a fetus with Down's syndrome because the quality of life of the retarded is not acceptable - and then have the baby suffer permanent brain damage from some illness. There are limits to control, and our children are always 'hostages to fortune'. Does the conscious, deliberate emphasis on control and 'standards of acceptability' prepare us for the reality of parenthood?

Another of the problems with the commodification process and its ensuing technology is that it allows some people, the richest and the most powerful, to buy their way out. Individual solutions are found while leaving social problems intact. Let us take as an example, the situation of having a retarded child. Why do I recoil at the thought of having as my son a grown man who drools and behaves like a child? If the person is, as most people with Down's syndrome are, able to learn to walk, to talk, to do simple tasks, then why do we so fear retardation?

One reason is what it does to our lives. You cannot even afford to die if you have a retarded child: what will become of her or him? This is just the extreme case of what is true of all children in our society - they are private property, and the economic and social burden is not shared. Support services for children in the United States are abysmal: it is United States policy to allow children to live in great poverty unless their individual parents and families can provide for them. With retarded or other damaged children, the stakes rise. One may be able to afford twenty years of expenses for a normal child, but a lifetime of expenses for a damaged child is just too much. The economic burden of a retarded or disabled child is beyond most of us. And the emotional burdens are inextricably tied up with the financial burdens.

The economic ties are basic. Most of the causes of disability and retardation among children are related to class position: one's chances of having a healthy child kept safe in a safe environmemt increase as we go up the socio-economic scale. The children of the poor suffer disproportionately from premature birth, from illness, from lead paint, from pollutants that parents in factories bring home on their clothes, from starvation 
and deficiency diseases, from cold dwellings, from overcrowding, from poor medical care. One of the few causes of disability and retardation that seems truly not to be class-linked is genetic disease: Down's syndrome, for example, appears to be associated exclusively with parental age, and not their class position. Haemophilia brought in by Queen Victoria destroyed the royal house ot Russia (5). As we increasingly solve genetic causes of disability, the population of the disabled will become even more disproportionately drawn from the population of the poor. As the wealthiest, and therefore the most powerful, in society increasingly buy their way out of retardation and disability, what will happen to the support services that do exist? Who will monitor the State schools for the retarded then?

Retardation and disability are social issues (6) threatening the stated values of our society: the values of equal opportunity and a fair share for everyone. We treat these social issues as individual troubles, to be individually solved. We treat them clinically, not politically. It fits in with the private property idea of children: the needs of your children are your problem.

From the point of view of the individual pregnant woman and her family, amniocentesis and selective abortion make great sense. I am not suggesting that we force wealthier and more educated people to have retarded children so that they will make that their political issue, their fight. I cannot accuse the people who offer the services or those who use them of doing the wrong thing. Mostly they are doing the only thing they can do. They are absolutely right when they say that they cannot afford, emotionally or financially, the burden of a disabled child. It is equally true that the infertile couple who can afford to buy a baby or to buy surrogate services may be making absolutely the right choice in purchasing such a baby or such services.

We cannot solve the social issues of dealing with the less-than-perfect people by making disability an individual trouble. We live in a society designed for the physically and mentally competent. It is children and old people who most often get hit by cars. Part of the issue then is redesigning the physical and social environment to meet the needs of all people. This is what the people in the disability rights movement are calling for. The decision to abort a fetus with spina bifida when you live in a fourth-floor apartment with no lift in a city designed without access for wheelchairs is not really an exercise in free choice.

But there are other issues as well. We must consider what it means to us to commodify life, to affix price tags to body parts. I include semen, ova, embryos, and fetuses as body parts. An important lesson can be learned from what happens when other body parts are available for purchase. Richard Titmuss's study of blood donation in England and in the United States, The Gift Relationship, provides a model (7). In England, where there is still resistance to total commodification of life, there is a right to health services, and blood is free. It is freely given. In the United States, blood is purchased either for money from paid donors, or for insurance, blood donors earning access to free blood for themselves and their $\overline{\overline{0}}$.

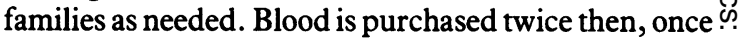
from the donor and once again from the blood bank. $\overrightarrow{\vec{\rho}}$ Titmuss's most dramatic finding is that the $\frac{\text { ? }}{7}$ commodification of blood does not work: where blood is purchased, it is scarce where needed, wasted where hoarded, in uneven, unreliable supply. Where blood is $\vec{\nabla}$ given freely, it is made freely available, and the supply is more even, with considerably less waste.

Titmuss's conclusions are not merely pragmatic, $\vec{\circ}$ regarding the most efficient way to distribute blood. He reaches beyond to analyse the social bond, to claim $\vec{\omega}$ a right to give, a right to be 'my stranger's keeper', a right which is violated when social policy supports commodification. He says of the altruistic English $\overrightarrow{-}$ blood donors:

'In not asking for or expecting any payment of money these donors signified their belief in the willingness of 을 other men to act altruistically in the future, and to combine together to make a gift freely should they have $\mathbb{D}_{\mathbb{R}}$ need for it. By expressing confidence in the behaviour of future unknown strangers they are thus denying the Hobbesian thesis that men are devoid of any distinctively moral sense (8).'

I want to argue from blood to gametes, to embyros, fetuses, to children. The commodification of life at bodies feeds upon itself and destroys, as Titmuss claims, the right to be altruistic. In a society which claims little joint responsibility for children, children $\frac{\emptyset}{\varnothing}$ are inevitably private property, and just as inevitably it $\varrho$ follows they will be sold and it further follows they will $\overrightarrow{\overrightarrow{0}}$ carry different price tags based on social desirability. 3 And some will be rejects, not salable at any price: too damaged, or the wrong colour, or too old, too long on the shelf.

In a world that does not value children, I do not know what it means to be altruistic with my seed. Could I give away an embryo, as many men have given or sold semen, when I know that child may grow to $\frac{3}{3}$ have needs that will be unmet? Is that kind of giving away altruism, or is it abnegation of responsibility? One of the things mothers who have given up babies tor $\frac{7}{O}$ adoption often say is that they just wish there was some $=$ way that the child could reach them if she or he needed $N^{N}$ them. In this world, in this society, we do not, cannot trust that the needs of all children, of our children, will N్ be met. Thus the right to give is lost.

As we lose the right to give, so too do we lose the right to accept, to accept our less-than-perfect, our needful children. In gaining the choice to control the quality of our children, we may rapidly lose the choice ${ }_{-}^{+}$ not to control the quality, the choice of simply accepting them as they are. The new reproductive $\overrightarrow{\mathbb{D}}$ technology is offered to us in terms of expanding $\frac{\text { }}{\mathbb{D}}$ choices. But it is always true that while new technologya opens up some choices, it closes down others. The new? choice is often greeted with such fanfare that the silent 
closing of the door on the old choice goes unheeded. To take a simple example, is there any meaningful way one could now choose horses over cars as a means of transportation? The new choice of a 'horseless carriage' eventually left us 'no choice' but to live with the pollution and dangers (as well as the convenience and speed, of course) of a car-based transportation system.

It happened first with the quantity of children. The oldest and most basic reproductive technology is the technology of fertility limitation. Self-imposed limits on fertility, through contraception or abortion, are the sine qua non of the reproductive rights movement. And yet, we must realise that the choice of contraception simultaneously closed down some of the choice for larger families. North American society is geared to small families, if indeed to any children at all. Without the provision of good medical care, day care, decent housing and schooling, children are a luxury item, fine if you can afford them.

And so it may also be with the technology of quality control: the ability to control the quality of our children may ultimately cost the choice of not controlling that quality. It is individual families, but it is most especially individual mothers who bear the costs of children, and the special costs of special children. How much any given child costs a mother is based not only on the condition of the child, but even more on the conditions of the mother's life. Any analysis of a woman's right to choose an abortion has to recognise the context in which the decision to abort is made, the circumstances in which the woman is placed. As Rosalind Petchesky has stated.

'The "right to choose" means very little when women are powerless ... Women make their own reproductive choices, but they do not make them just as they please; they do not make them under conditions which they themselves create, but under social conditions and constraints which they, as mere individuals, are powerless to change (9).'

We live in a system in which women and children are both disvalued, an anti-child, anti-woman society. It is women and children who are poor, whose needs are not being met. In this system women and children are often pitted against each other, competing for scarce resources. The mother finds herself becoming a resource: her own life, and specifically her own time, to be divided between herself and her children. Whatever the children get, it may very well be coming off the life of the mother - in time, in attention, in emotional support, sometimes in food and basic necessities. It is in this context that mothers are judged in terms of their willingness to sacrifice. The more she gives of herself to her children, the better a mother the society says she is. The more she holds back of herself, for herself, the more she runs the risk of being the 'wicked stepmother', evil in her selfishness.

When women and children are both disvalued, to speak for the rights or needs of either to be met is then to contribute to the devaluation of the other. When one adds to the situation the virtually total disvaluation of the needs of the disabled, the 'defective', 'in-valid' people, the place of selective abortion in our society is highlighted. Women know that children with 'special needs' make special demands. The society as a whole has shown itself unwilling to meet those demands - we are as a society unwilling to meet the ordinary needs of ordinary children. With wonderful and notable exceptions, fathers and other family members have not risen to the occasion. The burden of childrearing, of all childrearing, has fallen overwhelmingly on individual mothers. While those in the disability rights movement rightly resent the use of the word 'burden' to describe their lives, it is not a description unique to the disabled. Children, all children, can be described as burdensome when their needs fall almost exclusively on one person. Yes, they are also delightful, joyous, pleasures and treasures, whether able-bodied or disabled. But side by side with the joys of childrearing are the burdens; along with the pleasures come the sacrifices. The individual woman, or at very best, the individual couple or family, can demand more and more from the society for the child - and in fact making such demands becomes one of the chief responsibilities of the parents of a disabled child. But it is clear to us all that the society will not respond with openness and generosity, and most assuredly cannot be depended on to continue responding to the child's needs when the mother is no longer there. Even if the woman were to be willing to sacrifice herself entirely to meet the needs of the child, it might still not be enough.

It is in this context that amniocentesis and selective abortion are introduced, giving an illusion of choice, allowing individuals to believe that they have gained control over the products of conception. But the choices are made within an ever-narrowing structure. Issues of basic values, beliefs, the larger moral questions will be lost in this narrowing of choices, as decisions become pragmatic, often clinical, always individual. Irving Kenneth Zola puts it this way:

'Bombarded on all sides by realistic concerns (the escalations of costs) and objective evidence (genetics) and techniques (genetic counsellors), the basic value issues at stake will be obfuscated. The freedom to choose will be illusory. Someone will already have set the limits of choice (cuts in medical care and social benefits but not in defence spending), the dimensions of choice (if you do this then you will have an $\mathrm{X}$ probability of a defective child) and the outcomes of choice (you will have to endure the following social, political, legal and economic costs) (10).'

Thus the new technology of prenatal diagnosis and selective abortion does indeed offer new choices, but it also creates new structures and new limitations on choice. Because of the society in which we live, the choices are inevitably couched in terms of production 
and commodification, and thus do not move us to see new levels of genuine choice, or to provide us with genuine control.

Barabara Katz Rothman is Associate Professor of Sociology, Baruch College of the City University of New York. She is the author of In Labor: Women and Power in the Birthplace $W W$ Norton, 1982 and The Tentative Pregnancy: Prenatal Diagnosis and the Future of Motherhood. Her address is 17 Lexington Avenue, New York, NY 10010.

\section{References and notes}

(1) This phrasing was suggested by Rosalyn Weinman Schram.

(2) President's Commission for the Study of Ethical Problems in Medicine and Biomedical and Behavioral Research. Screening and counselling for genetic conditions: the ethical, social and legal implications of genetic screening, counselling and education programs. US Government Printing Office, 1983.

(3) Thomas W I, Thomas D S. Situations defined as real are real in their consequences. This excerpt from their work was printed in Stone G P, Farberman H A, eds. Social psychology through symbolic interaction, Waltham, Massachusetts: Xerox Publishing, 1970: 154-156, where the importance of this idea for the symbolic interactionist approach to sociology is discussed.

(4) Burke M B, Kolker A. Amniocentesis and the social construction of pregnancy: preliminary findings. Fournal of marriage and family relations. Forthcoming, expected date of publication 1987

(5) For an interesting account of the role of haemophilia in the Russian Revolution, see Massie R. Nicholas and Alexandria. New York: Atheneum Publishing, 1967.

(6) Mills C W. The sociological imagination. New York: Oxford University Press, 1969.

(7) Titmuss R. The gift relationship: from human blood to social policy. New York: Pantheum Books, 1972.

(8) See reference (7): 239.

(9) Petchesky R P. Reproductive freedom: beyond 'a woman's right to choose'. Signs: journal of women in culture and society 1980; 5: 674.

(10) Zola I K. Socio-medical inquiries: recollections, reflections and reconsiderations. Philadelphia: Temple University Press, 1983.

\section{Commentary}

\section{Margaret Stacey University of Warwick}

Dr Rothman's paper is timely. The implications of the new reproductive technologies are profound. They are generally thought of in terms of relieving the suffering of individual couples either by enabling them to overcome infertility or by eliminating the risk of bearing a handicapped child. Dr Rothman speaks of

\section{Key words}

Prenatal diagnosis; reproduction; abortion; gene therapy; handicap. amniocentesis and abortion when handicap is detected. $\stackrel{\mathbb{D}}{\stackrel{m}{ }}$ Already medical practitioners have 'genetic engineering' or 'gene therapy' on their agenda to remove 'faulty' genes before birth, although many of $\Rightarrow$ the techniques still require much development for $\stackrel{+}{+}$ clinical practice and are not so near as some imagine. When designed to prevent haemophilia, for example, 을 this must appear unobjectionable. But as Dr Rothman points out, to remove the possibility of having and $\stackrel{\mathbb{Q}}{\mathscr{Q}}$ accepting handicapped children may have unintended and at present unknown consequences in the reduction of choice, even though the new technologies may appear to offer more choice. Bearing and rearing a $\vec{\omega}$ handicapped child might become normatively unacceptable.

There are also ethical problems about which $\stackrel{\overparen{D}}{-}$ children it will be deemed unacceptable to bear, just as. there are already children deemed unsuitable for ${ }^{+}$ adoption, although far fewer than when there was $\mathrm{a}_{\infty}^{\infty}$ larger supply of unwanted children. There will beo problems about which potential children should have gene therapy. Who shall decide? Who will in practice decide? We already know that in the care of the handicapped the dividing line between medical and $\frac{\mathbb{}}{3}$ social intervention is continually blurred. Our social ability to define some other human beings as less than human (on account of their body shape, brain $\vec{\oplus}$ functioning, skin colour or sexual orientation) and the let ourselves off the hook of having to treat them as fellow human beings is already well known.

Dr Rothman is writing from US experience and, it seems, to a US audience. She herself (p.191) draws out contrasts between the UK and the US using ${ }_{\circ}^{\mathbb{D}}$ Titmuss's study of blood donation as an example not only of the morally correct way of doing things (in $\frac{0}{3}$ being based on altruism) but also the technically more efficient. This model is also used by the Council for Science and Society (1). Although the UK, like the US, is predominantly a capitalist society, we have hitherto consistently sought to prevent the intrusion of $-\sigma$ capitalist values into our health and welfare services. In the UK, issues associated with health and reproduction ${ }_{0}$ are less blatantly exploited for profit than in the US (2). However, many may be the indirect ways in which the $\mathrm{O}$ profit motive, or corporate or self interest permeates our health service (3). In the UK well over 90 per cent of our health care is provided on a collective basis and is not for profit. In the specific area of fertility we have $ᄋ$ turned our face against womb leasing (4). We do not $N$ permit the selling of children for adoption (5).

Dr Rothman presents a powerful plea against the intrusion of capitalist values, the values of the commodity market, into affairs of human reproduction $\bar{\Phi}$ for as she rightly indicates this has consequences for $\stackrel{?}{+}$ the basic values upon which society rests and the 0 respect in which we hold each other (6). Given the

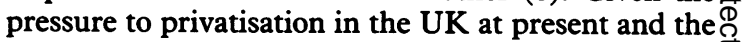
introduction of for-profit hospitals with international $\stackrel{\vec{Q}}{\circ}$ finance capital (7), it is well that those of us in the UK also heed her warnings, remembering that private 